\title{
PROGRAM MOBILE PUBLIC SERVICE KANTOR PELAYANAN PERIZINAN
} KOTA KEDIRI

\begin{tabular}{|c|c|}
\hline Nama Praktik yang Baik & $\begin{array}{l}\text { Program Mobile Public Service Kantor Pelayanan Perizinan } \\
\text { Kota Kediri }\end{array}$ \\
\hline Lokasi & Kota Kediri Provinsi Jawa Timur \\
\hline Tahun Implementasi & 2010 \\
\hline Institusi Pelaksana Utama & Kantor Pelayanan Perizinan Kota Kediri \\
\hline Kategori Institusi & Pemerintah Kota \\
\hline Penghargaan & - \\
\hline Kontak Person/Institution & $\begin{array}{l}\text { Agus Subariyanto Kepala Kantor Pelayanan Perizinan } \\
\text { (KPP) Kota Kediri, Jalan Basuki Rahmat No. } 15 \text { Kota } \\
\text { Kediri, (0358) 682345, wmw.perizinan.Kedirikota.info }\end{array}$ \\
\hline Mitra kerja & - \\
\hline Penulis dan Peneliti & M. Rizki Pratama dan Suci Styawan \\
\hline $\begin{array}{l}\text { 1. Mengapa program/kebijakan } \\
\text { tersebut muncul? }\end{array}$ & $\begin{array}{l}\text { Program ini labir labir karena masib buruknya kualitas } \\
\text { pelayanan perizinan di kota kediri serta rendahnya } \\
\text { kepemilikan SIUP (surat ijn usaba perdagangan). }\end{array}$ \\
\hline $\begin{array}{l}\text { 2. Apa tujuan program/kebijakan } \\
\text { tsb? }\end{array}$ & $\begin{array}{l}\text { 1) Mendekatkan pelayanan kepada masyarakat. 2) } \\
\text { Meningkatkan kesadaran masyarakat yang memiliki usaba } \\
\text { untuk segera mengurus perizinannya. 3) Meningkatkan } \\
\text { kesejabteraan bersama. }\end{array}$ \\
\hline $\begin{array}{l}\text { 3. Bagaimana gagasan tersebut } \\
\text { bekerja? }\end{array}$ & $\begin{array}{l}\text { Konsep program ini adalah mendekatkan layanan perizinan } \\
\text { kepada masyarakat dengan sistem 'jemput bola'. Dengan } \\
\text { fasilitas mobil keliling, layanan ini diharapkan dapat } \\
\text { membantu mempermudab masyarakat dalam mengurus } \\
\text { berbagai perizinan tanpa harus meninggalkan tempat } \\
\text { mereka beraktivitas sehingga mampu menjangkau seluruh } \\
\text { lapisan masyarakat. }\end{array}$ \\
\hline $\begin{array}{l}\text { 4. Siapa inisiatornya? Siapa saja } \\
\text { pihak-pihak utama yang terlibat? }\end{array}$ & $\begin{array}{l}\text { Inisiator utama adalah sebuah tim yang diberi nama tim } \\
\text { sembilan. Pihak lain yang terlibat adalah Kepala Kantor } \\
\text { Pelayanan Perizinan (KPP) Kota Kediri, Agus Subariyanto } \\
\text { yang didukung langsung oleb Walikota Kediri, Samsul } \\
\text { Ashar. }\end{array}$ \\
\hline $\begin{array}{l}\text { 5. Apa perubahan utama yang } \\
\text { dihasilkan? }\end{array}$ & $\begin{array}{l}\text { Masyarakat, terutama pengusaha UMKM dipermudah } \\
\text { dalam mendapatkan pelayanan perizinan. Tidak saja } \\
\text { dengan pelayanan yang tidak berbelit-belit, akan tetapi } \\
\text { pelayanan dapat mendatangi masyarakat langsung dengan } \\
\text { mobilitas kendaraan MPS. }\end{array}$ \\
\hline $\begin{array}{l}\text { 6. Siapa yang paling memperoleh } \\
\text { manfaat? }\end{array}$ & $\begin{array}{l}\text { Masyarakat, terutama pengusaba UMKM dan Pemerintah } \\
\text { Daerah Kota kediri. }\end{array}$ \\
\hline
\end{tabular}




\section{RINGKASAN}

Program MPS (Mobile Public Service), yaitu suatu program pelayanan berbasis mobile delivery yang memberikan pelayanan perizinan kepada masyarakat dengan cara mendatangi masyarakat secara langsung dengan menggunakan mobil. Visi dari program ini adalah mempermudah pelayanan perizinan bagi masyarakat. ${ }^{1}$ Program ini lahir lahir karena masih buruknya kualitas pelayanan perizinan di Kota Kediri ${ }^{2}$ serta rendahnya kepemilikan SIUP (Surat Izin Usaha Perdagangan). Berdasarkan data dinas perdagangan dan kantor pelayanan perizinan kota kediri hingga akhir tahun 2009 mengenai kepemilikan SIUP dan jumlah UMKM (Usaha Mikro, Kecil dan Menengah) menununjukkan bahwa kesadaran pengusaha UMKM di Kota Kediri mengurus SIUP masih sangat rendah, yaitu hanya sekitar 20 persen dari 18 ribu UMKM di Kota Kediri yang mempunyai SIUP. Sehingga hanya sekitar 3.600 UMKM yang sudah mengantongi SIUP. Sedangkan 14.400 UMKM belum mengurus SIUP. Banyaknya UMKM yang belum mengurus SIUP tersebut disebabkan salah satunya karena mereka merasa malas untuk berangkat ke kantor pelayanan perizinan (KPP) di Balai Kota Kediri. Mereka beralasan rumahnya jauh atau tidak bisa meninggalkan pekerjaan. Untuk itu perlu suatu sistem baru guna meningkatkan kesadaran pengusaha mengenai kepemilikan SIUP tanpa mempersulit mereka dengan prosedur yang berbelit-belit.

Tujuan dari program MPS yaitu antara lain ${ }^{3}:$ 1) Mendekatkan pelayanan kepada masyarakat. Dengan mendekatkan pelayanan kepada masyarakat maka diharapkan masyarakat tidak merasa

\footnotetext{
${ }^{1}$ Wawancara dengan kepala KPP. 24/08/12

2 Survei kabupaten/kota di Indonesia untuk bidang penanaman modal. 2009. Komite pemantau pelaksanaan otonomi daerah (KPPOD) dan badan koordinasi penanaman modal (BKPM).

${ }^{3}$ Wawancara dengan kepala KPP. 24/08/12
}

kesulitan lagi untuk mengurus perizinan usahnya. 2) Meningkatkan kesadaran masyarakat yang memiliki usaha untuk segera mengurus perizinannya, sebab hanya dengan memiliki legalitas suatu usaha dapat diakui keabsahannya secara hukum. 3) Meningkatkan kesejahteraan bersama. Ketika sudah memiliki legalitas maka suatu usaha dapat mengajukan kredit ke berbagai bank, dengan modal dari kredit tersebut maka para pengusaha UMKM dapat meningkatkan hasil produksi mereka sehingga meningkatkan kesejahteraan mereka sekaligus meningkatkan laju perekonomian kota kediri.

Konsep program ini adalah mendekatkan layanan perizinan kepada masyarakat dengan sistem 'jemput bola'. Dengan fasilitas mobil keliling, layanan ini diharapkan dapat membantu mempermudah masyarakat dalam mengurus berbagai perizinan tanpa harus meninggalkan tempat mereka beraktivitas sehingga mampu menjangkau seluruh lapisan masyarakat. Kegiatan MPS bertujuan untuk mensosialisasikan pentingnya perizinan sekaligus menjaring pendaftaran izin di sekitar lokasi MPS pada saat itu, baik itu di pasar-pasar atau di kelurahan-kelurahan. Perizinan sangat diperlukan sebagai legalitas usaha untuk akses ke pihak ketiga seperti kreditur, perbankan, tender pengadaan, dan kepercayaan usaha. Layanan MPS akan memberikan kemudahan proses pengurusan layanan perizinan kepada masyarakat. Ini merupakan prestasi yang baik bagi Kantor Pelayanan Perizinan Kota Kediri dalam usahanya menghapus stigma masyarakat yang menganggap perizinan berbelit-belit. Dengan semangat memberikan layanan yang dekat dengan masyarakat, kegiatan MPS ini menjadi salah satu program utama Kantor Pelayanan Perizinan (KPP) Kota Kediri dan mendapat apresiasi yang cukup bagus dari masyarakat dengan antusiasme mereka untuk datang ke loket MPS, baik sekedar bertanya maupun yang langsung mengurus izin usaha mereka. Kegiatan MPS ini secara periodik terus dilakukan dengan lokasi yang 
berpindah-pindah menyesuaikan dengan kebutuhan masyarakat

Dalam program MPS ini, terlihat beberapa aktor kebijakan yang sangat aktif dalam program MPS. Beberapa aktor utama yang terlibat dalam kebijakan ini antara lain, sebagai inisiator adalah Tim sembilan yang merupakan kelompok kerja pegawai KPP, kemudian penanggung jawab utama pelayanan di KPP yang terus berupaya melakukan inovasi yaitu Kepala Kantor Pelayanan Perizinan Kota Kediri, Agus Suhariyanto serta didukung langsung oleh Walikota Kediri, Samsul Ashar. Perubahan utama dari program ini adalah kini masyarakat yang ingin mendapatkan pelayanan perizinan yang telah disebutkan diatas semakin dipermudah dalam mendapatkan pelayanan perizinan. Tidak saja dengan pelayanan yang tidak berbelitbelit, akan tetapi pelayanan dapat mendatangi masyarakat langsung dengan mobilitas kendaraan MPS. Masyarakat tidak perlu lagi repot antri ke kantor pelayanan perizinan akan tetapi cukup menghubungi lewat telepon operator MPS untuk datang ke lokasi-lokasi strategis yang dekat dengan masyarakat. Masyarakat kini tidak perlu meninggalkan usaha sehari-harinya untuk antri mengurus perizinan karena sudah ada MPS yang akan mendatanginya langsung. Masyarakat tentu saja mendapatkan manfaat dengan program ini, terutama para pengusaha UMKM, selain layanan yang semakin dekat dan dipermudah, usaha dari masyarakat juga akan diakui legalitasnya sehingga dapat mengajukan kredit usaha ke berbagai bank. SIUP dan TDP (Tanda Daftar Perusahaan) sangat penting bagi
UMKM. Karena tanpa mengantongi dua surat tersebut, UMKM tidak bisa mendapatkan kredit. Sebab, salah satu kredit UMKM adalah harus mengantongi SIUP dan TDP. Ada dana miliaran rupiah untuk kredit UMKM. Dengan begitu usaha masyarakat juga akan semakin berkembang dengan meningkatnya nilai modal dan juga omzet yang semakin besar. Selain itu Pemerintah sendiri, sebagai penyedia layanan juga diuntungkan dengan adanya program ini. Semakin tingginya produktivitas masyarakat yang memiliki usaha maka akan dapat meningkatkan pendapatan asli daerah, sehingga dapat digunakan untuk membangun daerah untuk mencapai kesejahteraan bersama. 
PROFIL GOOD PRACTICE
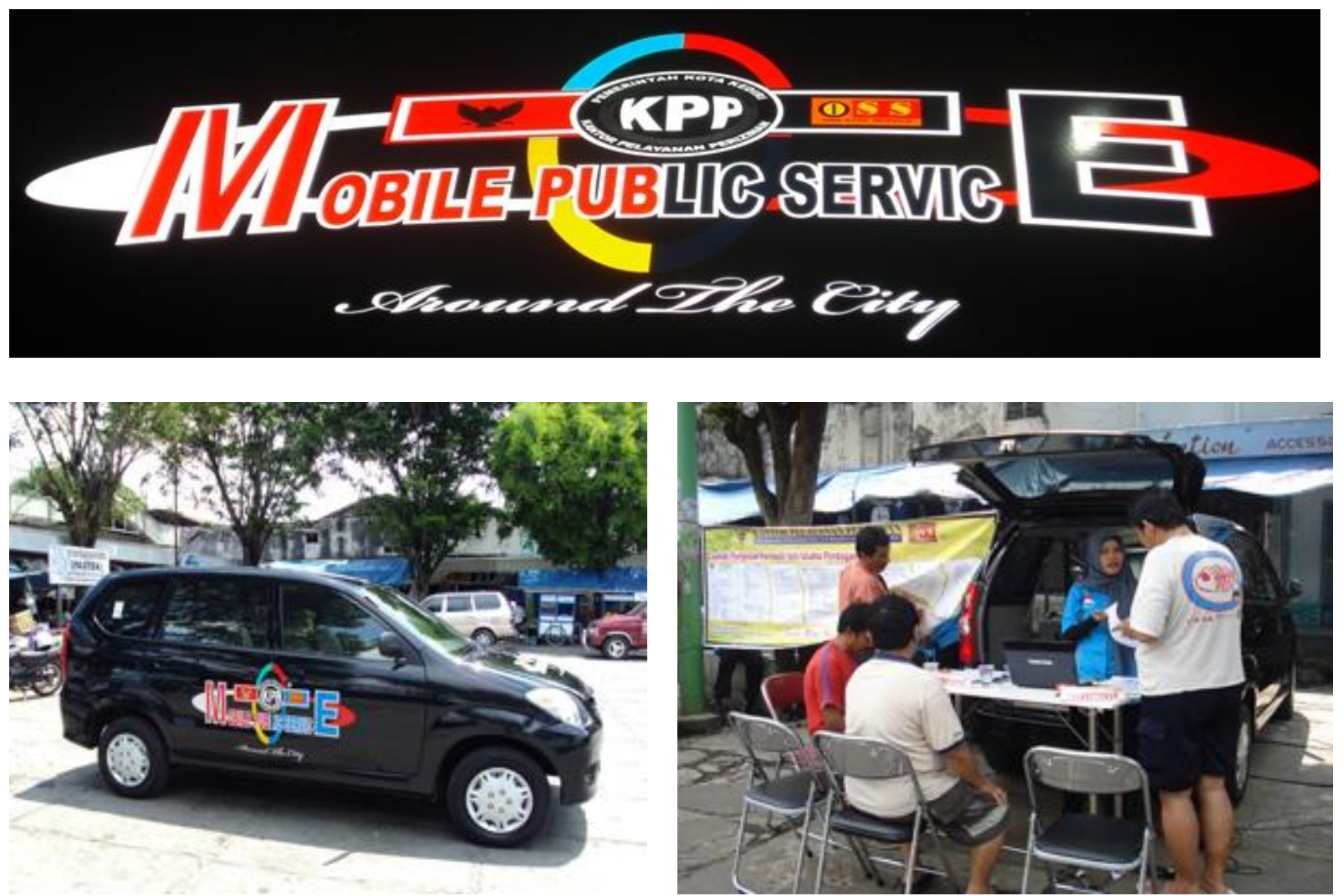

Gambar 1.1

Program Mobile Public Service Kantor Pelayanan Perizinan Kota Kediri

\section{LATAR BELAKANG : Buruknya Kualitas Pelayanan Perizinan Dan Rendahnya Kepemilikan SIUP}

Pada abad ke-21 ini upaya-upaya untuk mendorong terjadinya tata kelola pemerintahan yang baik terus dilakukan. Hampir di seluruh bagian di dunia ini pernah mendapatkan resep-resep khusus untuk dapat dikategorikan menjadi negara dengan tata kelola pemerintah yang paling baik. Salah satu resep yang menjadi trend hingga saat ini adalah konsep good governance, dimana oleh UNDP $^{4}$ negara yang dapat dikategorikan sebagai negara dengan good governance harus memiliki ciri-ciri sebagai berikut, yaitu : Participation, Rule of law, Transparancy, responsiveness, consensus orientation, equity, effectiveness and efficiency, accountability, strategic vision. Setiap item dalam konsep good governance harus diterapkan secara optimal

\footnotetext{
${ }^{4}$ Rahardjo Adisasmita. 2011. Manajemen pemerintah daerah. Jogjakarta : Graha ilmu, Hal 24
}

agar tata kelola yang diharapkan dapat tercipta. Dalam paradigma baru dalam pengelolaan pemerintahan yang dikemukakan oleh Denhardt dan Denhardt New Public Service (NPS). ${ }^{5}$ Birokrasi di bentuk dengan visi untuk melayani seluruh masyarakat tanpa terkecuali, yang memiliki uang atau tidak memiliki uang menurut paradigma NPS tetap akan mendapatkan pelayanan yang sama di depan birokrasi. Jadi, NPS menyatakan bahwa birokrasi harus melayani warga negara atau citizens berdasarkan nilai-nilai demokratis yang adil, bukan hanya melayani pelanggan atau konsumen yang berdasarkan nilai-nilai efektif dan efisien. NPS juga menyarankan segala kebijakan yang dilakukan oleh birokrasi harus memberikan efek kebaikan bersama, merupakan kebijakan yang didasarkan pada perwujudan mekanisme musyawarah bersama untuk menghasilkan

\footnotetext{
${ }^{5}$ Harbani Pasolong. 2010. Teori administasi publik. Bandung : Alfabeta, Hal 35
} 
konsensus, jadi tidak ada yang merasa dirugikan atau tidak memiliki hak yang sama.

Pada akhirnya tata kelola pemerintahan yang baik adalah dengan memberikan pelayanan secara optimal kepada setiap warga negara dengan mempertahankan nilai-nilai demokrasi yang berkeadilan. Inti dari pemerintahan dapat dikatakan adalah melayani masyarakat di segala bidang, baik di bidang kesehatan, pendidikan, kesejahteraan dan masih banyak bidang-bidang lain yang menjadi tanggung jawab pemerintah. Pemerintah yang mampu memberikan pelayanan yang optimal dapat dikatakan sebagai pemerintah dengan good governance, sedangkan yang masih belum mampu memberikan pelayanan secara optimal disebut dengan bad governance, dan yang lebih parah dari bad governance adalah poor governance.

Sebagai contoh, Singapura adalah salah satu negara dengan penyelenggaraan pelayanan publik yang baik. Dengan pelayanan publik yang baik, otomatis akan dapat mendorong pembangunan di sektorsektor lain sehingga tujuan pembangunan suatu negara akan lebih cepat tercapai. Selain itu pentingnya pelayanan publik yang diberikan oleh pemerintah kepada masyarakat luas adalah seperti yang diungkapkan oleh Agus Dwiyanto, yaitu pelayanan publik melibatkan kepentingan semua unsur governance. Pemerintah sebagai reperesntasi negara, masyarakat sipil, dan mekanisme pasar memiliki kepentingan dan keterlibatan yang tinggi dalam ranah ini. Pelayanan publik memiliki high stake dan menjadi pertaruhan yang penting Keberhasilan sebuah rezim dan penguasa dalam membangun legitimasi kekuasaan sering dipengaruhi oleh kemampuan mereka dalam menyelenggarakan pelayanan publik yang baik dan memuaskan warga ${ }^{6}$.

\footnotetext{
${ }^{6}$ Agus Dwiyanto (Ed). 2008. Mewujudkan good governance melalui pelayanan publik. Jogjakarta : Gadjah mada university press, Hal 24.
}

Berdasarkan kalimat diatas maka dapat dikatakan bahwa pelayanan publik merupakan inti dari pemerintahan, sebab masyarakat akan dapat menilai keberhasilan atau kegagalan suatu pemerintahan dari pelayanan publik yang telah diberikan kepada mereka. Hampir setiap saat masyarakat selalu berinteraksi dengan pelayanan yang diberikan oleh pemerintah, bahkan dari lahir sampai dengan meninggal dunia. Pelayanan publik yang baik akan membekas di hati masyarakat sedangkan pengalaman mendapatkan pelayanan publik yang buruk akan menimbulkan kecaman dari masyarakat luas, akibatnya pemerintah mungkin tidak dapat lagi dipercaya oleh masyarakat.

Selama ini yang dapat dilihat dari penyelenggaraan pelayanan publik di Indonesia, masih terlalu banyak masalah yang menyebabkan pelayanan publik menjadi tidak optimal. Misalnya tata kelola pemerintahan Indonesia masih tergolong buruk $^{7}$. Hal itu juga menyebabkan pelayanan kepada masyarakat menjadi terabaikan karena pemerintah masih disibukkan dengan masalah internal organisasinya. Selain itu juga Indonesia pada tahun 2002 juga dinobatkan sebagai negara terkorup di Asia ${ }^{8}$, akibat korupsi tersebut anggaran-anggaran yang seharusnya digunakan untuk memberikan pelayanan publik secara optimal kepada masyarakat menjadi terpangkas dan pelayanan publik yang diselenggarakan menjadi sangat buruk.

Oleh karena itu, menyadari banyaknya masalah dalam pelayanan publik dan berdasarkan pada keinginan mulia untuk memperbaiki pelayanan publik di Indonesia. Pada tahun 2009 pemerintah mengeluarkan Undang-undang Nomor 25 tahun 2009 mengenai pelayanan publik. Dengan

\footnotetext{
${ }^{7}$ Hasil Survei GDS pada 2002 dalam Agus Dwiyanto (Ed). 2008. Mewujudkan good governance melalui pelayanan publik. Jogjakarta : Gadjah Mada University Press. Hal 21

${ }^{8}$ Hasil survai PERC pada 2002 dalam Jusuf Irianto, dkk. 2009. Manajemen sumber daya manusia berbasis kompetensi untuk pelayanan publik. Surabaya : Airlangga University Press. Hal 75
} 
dikeluarkannya UU tersebut diharapkan dapat memberikan dasar hukum yang komprehensif dalam malaksanakan pelayanan publik sehari-hari maupun untuk mengadakan perbaikan-perbaikan dalam pelayanan publik. UU 25 tahun 2009 memberikan beberapa pengertian kepada masyarakat sebagai penerima pelayanan publik, yaitu negara berkewajiban melayani setiap warga negara dan penduduk untuk memenuhi hak dan kebutuhan dasarnya dalam kerangka pelayanan publik, membangun kepercayaan masyarakat atas pelayanan publik yang dilakukan penyelenggara pelayanan publik merupakan kegiatan yang harus dilakukan seiring dengan harapan dan tuntutan seluruh warga negara dan penduduk tentang peningkatan pelayanan publik, Sebagai upaya untuk mempertegas hak dan kewajiban setiap warga negara dan penduduk serta terwujudnya tanggung jawab negara dan korporasi dalam penyelenggaraan pelayanan publik, diperlukan norma hukum yang memberi pengaturan secara jelas, sebagai upaya untuk meningkatkan kualitas dan menjamin penyediaan pelayanan publik sesuai dengan asas-asas umum pemerintahan dan korporasi yang baik serta untuk memberi perlindungan bagi setiap warga negara dan penduduk dari penyalahgunaan wewenang di dalam penyelenggaraan pelayanan publik. Oleh karena itu, dengan terbitnya UU 25 tahun 2009 ini merupakan sebuah titik terang menuju pelayanan publik yang lebih baik.

Selanjutnya pemerintah berusaha memperbaiki pelayanan publik, sebagai perwujudan adalah dilakukannya terobosan baru dalam layanan publik dalam bentuk inovasi-inovasi ${ }^{9}$. Dengan adanya inovasiinovasi dalam pelayanan publik diharapkan proses perbaikan pelayanan publik menjadi lebih cepat dan menghasilkan kualitas pelayanan yang lebih baik. Inovasi dalam beberapa tahun terakhir menjadi kata kunci dalam pelayanan publik di Indonesia. Banyak daerah-daerah melakukan berbagai jenis inovasi pelayanan publik, akan tetapi

\footnotetext{
${ }^{9}$ Ibid., Hal 81.
}

justru banyak daerah yang gagal dalam menerapkan inovasi tersebut. Beberapa inovasi pelayanan publik pemerintah daerah di Indonesia yang dinilai berhasil ${ }^{10}$, antara lain Pembatasan Jumlah Siswa Perkelas Dan Penguatan Insentif Bagi Praktisi Pendidikan di Kabupaten Tanah Datar, Sumatra Barat, Kupon Pelayanan Bidan di Kabupaten Pemalang, Jawa Tengah, Pembangunan Komunitas Belajar Bagi Anak di Kabupaten Polman, Sulawesi Barat, Meningkatkan Transparansi Anggaran di Kota Bandung, Jawa Barat, Program Air Bersih Dan Kesehatan di Kabupaten Lumajang, Jawa Timur, Reformasi Jaminan Kesehatan di Kabupaten Jembrana, Bali, Program Community Block Grant di Kota Blitar, Jawa Timur, Proses Perencanaan Partisipatif di Kabupaten Maros, Sulawesi Selatan, Reformasi Pegawai Negeri di Kabupaten Boalemo, Gorontalo. Program-program inovasi diatas dapat menginspirasi daerah lain untuk dapat memberikan pelayanan publik yang terbaik bagi masyarakat.

Semua paparan diatas menghasilkan titik akhir dari inovasi pelayanan publik adalah peningkatan kualitas pelayanan kepada publik. Salah satu pelayanan publik yang mendapat perhatian serius dari pemerintah pusat adalah pelayanan perizinan, sebab dengan kualitas pelayanan perizinan yang bagus maka pendapat negara atau pemerintah akan dapat ditingkatkan, terutama pelayanan perizinan yang berhubungan dengan usaha, penanaman modal serta investasi. Pelayanan perizinan dapat didefinisikan sebagai segala bentuk jasa pelayanan yang pada prinsipnya menjadi tanggung jawab dan dilaksanakan oleh instansi pemerintah di pusat, di daerah dan di lingkungan badan usaha milik negara atau badan usahan milik daerah, baik dalam rangkan upaya pemenuhan kebutuhan masyarakat maupun dalam rangka pelaksanaan ketentuan peraturan perundangundangan, yang bentuk produknya

\footnotetext{
${ }^{10}$ Inovasi pelayanan pro-miskin : sembilan studi kasus di Indonesia. 2006. Bank dunia
} 
pelayanannya adalah izin atau warkat ${ }^{11}$. Oleh karena itu pada tahun 2003 diterbitkan keputusan menteri pendayagunaan aparatur negara nomor 63/KEP/M.PAN/7/2003 tentang pedoman umum penyelenggaraan pelayanan publik. Berdasarkan pedoman tersebut, pemerintah daerah dapat membuat kantor pelayanan perizinan dengan sistem satu atap, satu pintu maupun kombinasi antar keduanya. Hingga saat ini sudah banyak pemerintah daerah yang mendirikan kantor pelayanan perizinan dengan sistem seperti yang disebutkan diatas, akan tetapi hasil yang diharapkan yaitu meningkatknya kualitas pelayanan perizinan yang akan dapat meningkatkan pendapatan daerah maupun nasional belum dapat tercapai secara maksimal. Seperti kantor pelayanan perizinan kota kediri yang sudah didirikan sejak tahun 2003 akan tetapi berdasarakan penelitian komite pemantauan pelaksanaan otonomi daerah dan badan koordinasi penanaman modal nasional pada tahun 2009 kota kediri termasuk dalam kategori 10 kota di Indonesia dengan pelayanan perizinan terburuk ${ }^{12}$.

\section{Grafik 1.1}

\section{Kota Dengan Pelayanan Perizinan} Terbaik Dan Terburuk

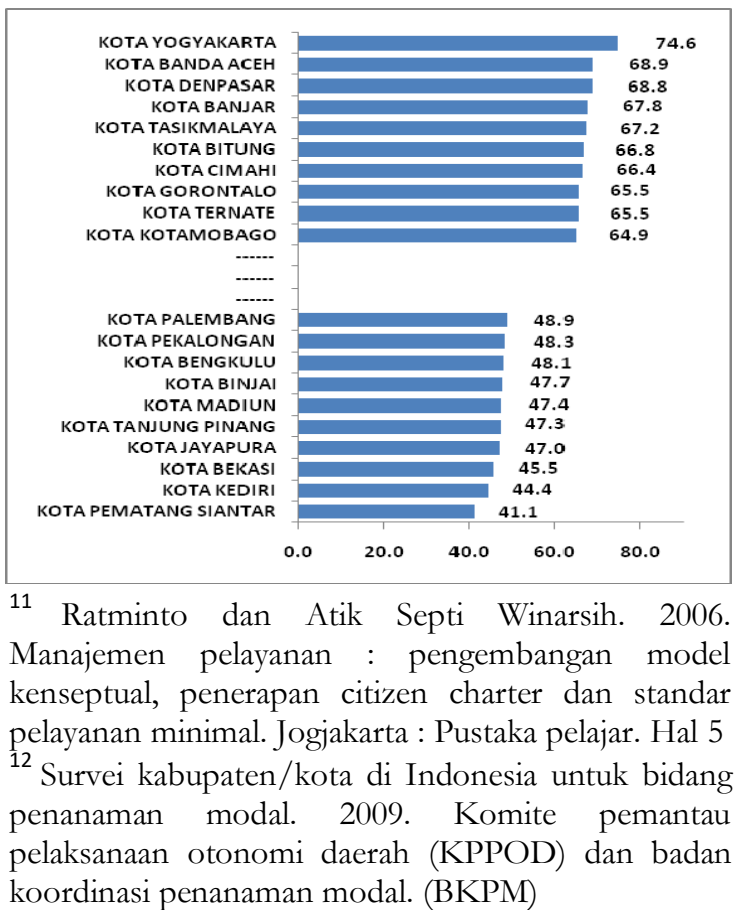

Sumber : Survei KPPOD dan BKPM tahun 2009

Masalah lain yang menjadi fokus KPP adalah masih rendahnya jumlah UMKM yang memiliki SIUP (Surat Izin Usaha Perdagangan). Berdasarkan data dinas perdagangan dan kantor pelayanan perizinan kota kediri hingga akhir tahun 2009 mengenai kepemilikan SIUP dan jumlah UMKM (Usaha Mikro, Kecil dan Menengah) menunjukkan bahwa kesadaran pengusaha UMKM di Kota Kediri mengurus SIUP masih sangat rendah, yaitu hanya sekitar 20 persen dari 18 ribu UMKM di Kota Kediri yang mempunyai SIUP. Sehingga hanya sekitar 3.600 UMKM yang sudah mengantongi SIUP. Sedangkan 14.400 UMKM belum mengurus SIUP. Kedua permasalahan tersebut jelas akan dapat menimbulkan dampak bagi pembangunan di kota kediri, jika kualitas pelayanan perizinan buruk maka perekonomian dapat juga menjadi buruk demikian pula rendahnya kepemilikan SIUP akan membuat para pengusaha UMKM tidak akan mendapatkan kredit secara resmi untuk meningkatkan usahanya. Dua hal tersebut merupakan persoalan utama yang melatarbelakangi lahirnya program MPS.

Kemudian berdasarkan masalah diatas, kelompok sosial yang paling merasakan dampak dari persoalan tersebut adalah para pengusaha $\mathrm{UMKM}^{13}$, sebab dengan buruknya kualitas pelayanan perizinan membuat mereka malas untuk mengurus izin usaha mereka, sehingga mereka tidak memiliki SIUP yang seharusnya dapat digunakan untuk memaksimalkan produksi UMKM mereka dengan mengajukan pinjaman/kredit ke berbagai bank ataupun program pinjaman pemerintahan lainnya. Salah satu syarat untuk mengajukan pinjaman/kredit tersebut adalah UMKM harus memiliki SIUP sehingga diakui legalitasnya. Sebenarnya potensi UMKM di kota kediri adalah berjumlah 14 ribu-an, namun hampir tiga perempatnya belum berdaya saing karena

${ }^{13}$ Wawancara dengan staf KPP. 06/08/12 
keterbatasan akses pada sumber daya, khususnya permodalan. ${ }^{14}$

Berdasarkan fakta tersebut maka KPP berusaha mencari upaya yang dapat meningkatkan kualitas pelayanan perizinan, sekaligus meningkatkan kepemilikan SIUP. Jalan untuk membuat sistem baru dengan inovasi akhirnya dipilih oleh KPP, yaitu dengan membuat suatu program pelayanan berbasis mobile delivery yaitu program mobile public service (MPS) guna mengatasi persoalan-persoalan diatas.

\section{INISIASI : Tim Sembilan Sebagai Inisiator Utama}

Inisiator dalam program MPS ini merupakan sebuah kelompok pegawai KPP yang tergabung dalam tim sembilan ${ }^{15}$. Tim sembilan ini dibentuk oleh kepala KPP yang beranggotakan sembilan orang pegawai yang dianggap kompeten dan memiliki semangat perubahan. Tim sembilan ini berisikan pegawai dengan usia 30 tahunan sehingga dianggap masih memiliki semangat perubahan yang lebih baik daripada pegawai yang sudah senior dan mendekati usia pensiun. Tim sembilan ini dibentuk untuk mengatasi berbagai permasalahan dalam pelayanan perizinan, akhirnya dalam beberapa kesempatan diskusi dan rapat tim ini mencetuskan sebuah program pelayanan perizinan yang lebih menonjolkan sisi untuk mempermudah dan mendekatkan pelayanan perizinan kepada masyarakat yaitu diberi nama program mobile public service (MPS).

Sebelum program MPS berjalan terdapat faktor-faktor yang mendorong tim sembilan ini untuk mencetuskan program MPS, antara lain dari faktor eksternal, yaitu faktor yang berada di luar organisasi adalah : 1) Masih buruknya pelayanan perizinan sehingga harus ada perubahan dalam sistem pelayanan, 2) Rendahnya jumlah UMKM

\footnotetext{
${ }^{14}$ Praktek-praktek yang baik dalam pemberdayaan UKM. 2009. LGSP,Usaid \& Dirjen PU Depdagri. Seri manajemen pelayanan publik.

${ }^{15}$ Wawancara dengan staf KPP. 06/08/12
}

yang memiliki SIUP, 3) Adanya pungli dalam pelayanan perizinan. Kemudian dari faktor pendorong internal yang berasal dari dalam organisasi, yaitu adanya keinginan untuk berubah menuju pelayanan perizinan yang lebih baik. Dari segi sumber daya yang mendukung tim sembilan adalah adanya dukungan modal sosial dari para pegawai KPP sendiri misalnya adanya generasi muda dalam KPP yang menyadari perubahan organisasi itu diperlukan untuk beradaptasi dengan lingkungan. Kemudian dari segi leadership kepala KPP sendiri mampu memimpin organisasi untuk menuju perubahan.

Tim sembilan sendiri dapat disebut sebagai inisiator utama dalam program MPS, yang menarik dari tim ini adalah latar belakang kelompok inisiator adalah pegawai KPP yang berada di usia tergolong muda sehingga masih memiliki semangat yang tinggi untuk melakukan perubahan, bahkan salah satu anggota tim sembilan yang berperan sebagai motor dalam tim pernah memiliki catatan karir di sektor swasta. Jadi, berdasarkan pengalamannya bekerja di sektor swasta maka terjadi sharing pengetahuan dalam tim sembilan antara pengetahuan di sektor swasta maupun sektor publik, sehingga dapat memantik perubahan organisasi untuk menjadi lebih baik.

Hasil dari tim sembilan tersebut tentu saja berupa inovasi program MPS yang dicetuskan melalui berbagai diskusi dan rapat yang dilakukan oleh tim sembilan. Ide awal program MPS dapat dikatakan terinspirasi dari program-program mobile dari organisasi publik lainnya, misalnya SIM keliling SAMSAT POLRI dan mobil pelayanan keliling BPN. ${ }^{16}$ Berjalannya program MPS mulai dari inisiasi, perencanaan, implementasi maupun evaluasi tidak ditemukan hambatan yang berupa penolakan dari stakeholder, yang ada justru dukungan penuh dari masyarakat. Tujuan inisiasi disini adalah untuk mengatasi permasalahan utama dalam pelayanan

\footnotetext{
${ }^{16}$ Wawancara dengan staf KPP. 06/08/12
} 
perizinan yaitu buruknya pelayanan pelayanan perizinan dan masih rendahnya jumlah UMKM yang memiliki SIUP. Kemudian agar program dapat dianalisis kefektifannya makan perlu dirumuskan suatu tujaun program, dalam proses perumusan tujuan sendiri dilakukan dengan cara-cara yang partisipatif, akan tetapi konsep partisipasi yang digunakan dalam hal ini adalah partisipasi sebatas di dalam lingkungan kantor pelayanan perizinan sendiri, yaitu partisipasi dari pegawai KPP yang tergabung dalam tim sembilan. Sedangkan partisipasi masyarakat kurang berperan dalam proses perumusan tujuan, sehingga dapat disimpulkan bahwa belum terjadi keseimbangan peran antar stakeholder yang memiliki kepentingan, yaitu antara pemerintah (government), rakyat (citizen atau civil society) dan usahawan (business), yang seharusnya ketiga komponen itu mempunyai tata hubungan yang sama dan sederajat ${ }^{17}$.

\section{TAHAP IMPLEMENTASI Layanan Jemput Bola}

Desain awal inisiatif program MPS terbentuk berdasarkan hasil diskusi dan rapat antara tim sembilan yang menghasilkan sebuah rekomendasi yang pada akhirnya disetujui oleh kepala KPP Desain ini memberikan sebuah sistem jemput bola bagi masyarakat. Sebenarnya jika dirunut jauh sebelumnya, pada awalnya kepala KPP terlebih dahulu memberikan brainstorming kepada seluruh pegawai KPP agar merubah budaya kerja yang lebih melayani kepada masyarakat. Seperti yang terlihat dalam peta berikut :

\footnotetext{
${ }^{17}$ Miftah Thoha. 2010. Birokrasi dan politik di Indonesia. Jakarta : PT Rajagrafindo persada. Hal 63
}

Peta I.I

Perubahan Budaya Kerja KPP

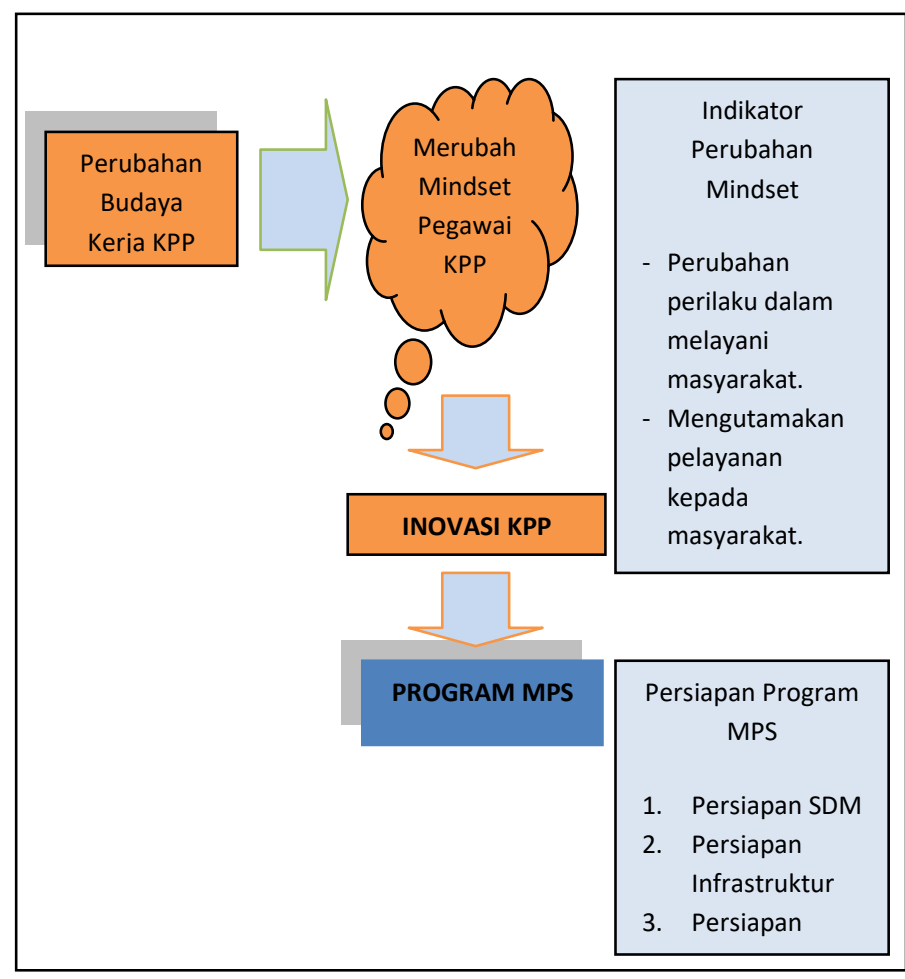

Sumber: Wawancara dengan Kepala KPP

Kemudian sesuai dengan peta diatas untuk melaksanan sebuah pelayanan yang berbasis jemput bola maka diperlukan berbagai macam persiapan yang harus dilakukan, antara lain : 1) Sumber daya manusia. Hal yang dilakukan adalah mempersiapkan sumber daya manusia yang akan diterjunkan ke masyarakat untuk melaksanakan sistem yang baru. Langkah penting yang dilakukan oleh kepala KPP adalah melakukan perubahan mindset para pegawai KPP agar memiliki sikap untuk melayani masyarakat dan bukan sebaliknya ${ }^{18}$. Selain itu juga dilakukan pembagian tugas antar pegawai KPP yang ada di kantor dan dengan pegawai yang sedang ada di lapangan. 2) Infrastruktur. Untuk melayani masyarakat dengan sistem jemput bola maka infrastruktur utama yang harus ada adalah kendaraan roda empat/mobil yang difungsikan sebagai lokasi pelayanan yang memiliki mobilitas yang tinggi untuk

\footnotetext{
${ }^{18}$ Wawancara dengan kepala KPP. 24/08/12
} 
berpindah tempat. Kemudian dari segi alat kelengkapan yang lain diambil dari KPP sendiri ataupun melakukan pembelian. 3) Sosialisasi. Masyarakat perlu tahu akan adanya sistem baru ini, oleh karena itu KPP membuat surat pemberitahuan kepada masyarakat akan adanya sistem yang baru tersebut. Selain itu juga melalui berbagai macam strategi pemasaran kepada masyarakat, misalnya dengan mendatangkan Walikota Kediri untuk ikut serta dalam pelaksanaan sistem yang baru agar masyarakat tertarik untuk mengikutinya.

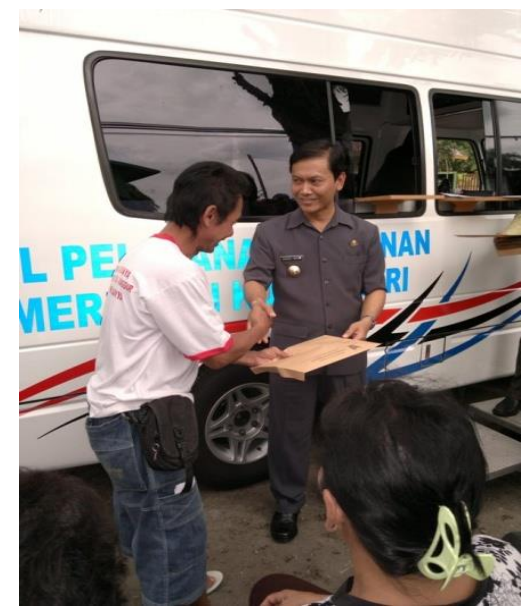

Gambar 1.2

\section{Walikota Kediri dalam program MPS}

Untuk lebih menarik lagi perhatian masyarakat untuk ikut serta mendaftarkan perizinan usaha dengan sistem yang baru tersebut maka diberikanlah hadiah secara cuma-cuma berupa kaset $d v d$ yang berisi video profil investasi kota kediri dan album perdana persik mania. Cara-cara yang dilakukan oleh KPP dalam menarik masyarakat dapat dikatakan sebagai marketing sosial. Seperti halnya memasarkan sebuah produk, perencanaan marketing sosial juga menggunakan terminologi pemasaran pada umumnya yakni $4 \mathrm{P}^{19}$, yaitu : 1) Product: Ide gagasan, dalam hal ini yang diberikan oleh program MPS adalah ide pelayanan jemput bola yang dapat memudahkan pelayanan perizinan kepada

\footnotetext{
${ }^{19}$ Falih Suaedi dan Bintoro Wardiyanto (Ed). 2010. Revitalisasi administrasi negara : reformasi birokrasi dan e-government. Jogjakarta : Graha ilmu. Hal 193
}

masyarakat. 2) Price : Apa yang dibayarkan oleh masyarakat untuk mengurus perizinan melalui program MPS adalah tidak dipungut biaya, dan bahkan mendapatkan hadiah dari KPP. 3) Place : Program MPS memiliki mobilitas yang tinggi sehingga dapat berpindah-pindah lokasi pelayanan perizinan sesuai dengan kebutuhan masyarakat. 4) Promotion: Program MPS juga menggunakan media massa sebagai sarana promosi, misalnya dengan rubrik khusus dalam koran radar kediri yang diberi nama galery KPP yang menginformasikan masyarakat tentang penyelenggaraan program MPS. Pada akhirnya sistem pelayanan perizinan dengan sistem jemput bola ini diberi nama program mobile public service (MPS) yaitu suatu program pelayanan berbasis jemput bola yang memberikan pelayanan perizinan kepada masyarakat dengan cara mendatangi masyarakat secara langsung dengan menggunakan mobil.

Lebih lanjut lagi menyentuh level pelaksanaan program MPS yaitu proses implementasi pada dasarnya mekanisme yang digunakan pada program MPS adalah sama dengan mekanisme perizinan di KPP seperti biasanya akan tetapi yang berbeda adalah menggunakan mobil dan dilakukan diluar kantor ${ }^{20}$. Dalam istilah KPP adalah hanya pindah kantor. Perbedaan yang lain juga terletak pada waktu pelayanan perizinan. Program MPS memiliki waktu penyelesaian akhir surat perizinan yang lebih cepat daripada di kantor pelayanan perizinan. Khusus untuk UMKM melalui program MPS surat perizinan dapat diselesaikan dalam tempo satu hari saja.

\footnotetext{
${ }^{20}$ Wawancara dengan staf KPP. 13/08/12
} 
Tabel 1.1

Perbedaan Pelayanan Perizinan Program MPS Dengan Perizinan Di Dalam Kantor

\begin{tabular}{|l|l|l|}
\hline Pembeda & \multicolumn{1}{|c|}{ MPS } & \multicolumn{1}{|c|}{ Kantor } \\
\hline Lokasi & $\begin{array}{l}\text { Berpindah- } \\
\text { pindah/sesuai } \\
\text { kebutuhan } \\
\text { masyarakat }\end{array}$ & $\begin{array}{l}\text { Di dalam } \\
\text { kantor }\end{array}$ \\
\hline $\begin{array}{l}\text { Waktu } \\
\text { Layanan }\end{array}$ & $\begin{array}{l}\text { Hari rabu- } \\
\text { kamis/sesuai } \\
\text { kebutuhan } \\
\text { masyarakat }\end{array}$ & Senin-jum'at \\
\hline Prioritas & $\begin{array}{l}\text { Perizinan } \\
\text { UMKM }\end{array}$ & $\begin{array}{l}\text { Tidak ada } \\
\text { prioritas }\end{array}$ \\
\hline $\begin{array}{l}\text { Lama } \\
\text { Penyelesaian } \\
\text { Perizinan }\end{array}$ & $\begin{array}{l}\text { Maksimal Satu } \\
\text { hari (khusus } \\
\text { untuk UMKM) }\end{array}$ & $\begin{array}{l}\text { Minimal tiga } \\
\text { hari }\end{array}$ \\
\hline
\end{tabular}

Sumber: Wawancara dengan staf KPP

Proses implementasi sendiri pasti membutuhkan dukungan dari seluruh stakeholder agar tujuan yang diinginkan dapat tercapai. Disini sebuah catatan penting mengenai bagaimana mengkonsolidasi/memobilisasi dukungan terhadap program MPS terutama dari dukungan sumber daya dari dalam organisasi sendiri. Terlihat dari keseriusan tim sembilan dalam merumuskan dan memobilisasi seluruh pegawai KPP agar mendukung program MPS, terbukti dengan diterapkannya sistem rolling pegawai dalam melaksanakan MPS sehingga seluruh pegawai KPP pernah merasakan melayani masyarakat dengan menggunakan mobil di luar kantor. Dari dukungan politik sendiri, Walikota Kediri sangat mendukung program MPS dengan bersedia menghadiri pelaksanaan program MPS di berbagai kesempatan agar menarik perhatian masyarakat. Kemudian dari segi sarana dan prasarana awalnya tim sembilan kesulitan untuk mendapatkan mobil yang akan digunakan untuk program MPS, setelah melalui berbagai macam diskusi dan rapat akhirnya kepala KPP bersedia berkorban dengan menggunakan mobil dinasnya untuk digunakan sebagai mobil MPS. Hingga kini mobil MPS sudah berganti dengan diberikannya hibah satu unit mobil dari perusahaan swasta dengan kapasitas yang lebih besar daripada sebelumnya sehingga dapat meningkatkan pelayanan kepada masyarakat. Dari awal hingga saat ini tidak ada penolakan terhadap program MPS, baik dari masyarakat maupun dari lingkungan pemerintah sendiri. Justru dukungan terhadap program MPS ini semakin besar, yakni masyarakat kini dapat menghubungi melalui pesawat telepon KPP agar menerjunkan program MPS di lokasi tertentu. Kemudian agar diketahui masalahmasalah apa saja yang timbul dan memperoleh data-data yang penting dalam proses perijinan ketika implementasi program MPS maka diperlukanlah proses evaluasi. Dari segi proses evaluasi program MPS sendiri masih menggunakan instrumen yang sederhana, yaitu memperbandingankan jumlah perizinan yang berhasil dikeluarkan setiap program MPS dilakukan dalam satu hari ${ }^{21}$. Tindak lanjut dari proses evaluasi ini adalah digunakanya data masyarakat yang sudah mengurus perizinan sebagai perkiraan awal seberapa besar masyarakat yang belum mengurus perizinan sehingga berpeluang untuk didatangi oleh program MPS selanjutnya. Selain itu juga dilakukan evaluasi oleh pimpinan KPP setiap selesai melaksanakan program MPS, yaitu dengan metode rapat untuk mencari tahu permasalahan apa saja yang terjadi, misalnya rendahnya partisipasi masyarakat dalam mengikuti program MPS sehingga harus segera diberikan solusi dengan diskusi bersama.

\footnotetext{
${ }^{21}$ Wawancara dengan staf KPP. 13/08/12
} 
III. DAMPAK

SUBSTANTIF :

Peningkatan Kualitas Pelayanan

Perizinan Dan Peningkatan Kepemilikan SIUP Bagi UMKM

Sejak tahun 2010 hingga kini tahun 2012 program MPS masih tetap berjalan. Dampak yang dihasilkan juga cukup nyata, mengingat program MPS merupakan inovasi yang dilakukan oleh KPP yang benar-benar menyentuh masyarakat secara langsung. Terbukti terjadi peningkatan kualitas pelayanan perizinan di kota kediri berdasarkan survei KPPOD pada tahun 2011, yaitu jika pada tahun 2009 berada pada sepuluh besar terbawah nasional kemudian meningkat secara siginifikan menjadi sepuluh besar terbaik secara nasional ${ }^{22}$. Kemudian dampak selanjutnya adalah adanya kenaikan jumlah kepemilikan SIUP dari UMKM secara signifikan pada tahun 2011 kepemilikan SIUP para pengusaha UMKM yang mendaftar dari program MPS mencapai angka 665 izin dan bahkan menurut data tahun 2012 hingga bulan juli saja angka kepemilikan SIUP sudah meningkat yang mencapai 624 izin ${ }^{23}$. Peningkatan tersebut tercatat sangat tinggi dibandingkan dengan data kepemilikan SIUP sebelumnya yang hanya berkisar antara $300 \mathrm{~s} / \mathrm{d} 500$ SIUP per tahun. ${ }^{24}$

Tabel 1.2

Jumlah SIUP tahun 2005-2012

\begin{tabular}{|l|l|}
\hline \multicolumn{1}{|c|}{ Tahun } & Jumlah SIUP \\
\hline $\begin{array}{l}2012 \text { (Bulan } \\
\text { Juli) }\end{array}$ & 624 \\
\hline 2011 & 665 \\
\hline 2010 & - \\
\hline 2009 & 505 \\
\hline 2008 & 398 \\
\hline 2007 & 398 \\
\hline 2006 & 386 \\
\hline 2005 & 386 \\
\hline
\end{tabular}

Sumber : Kediri Dalam Angka Tahun 2011

\footnotetext{
${ }^{22}$ Survei tata kelola ekonomi daerah 2011. Komite pemantau pelaksanaan otonomi daerah (KPPOD)

${ }^{23}$ Data akumulasi SIUP MPS 2011 \& 2012

${ }^{24}$ Kediri dalam angka tahun 2011. BPS kota kediri
}

Fakta ini menunjukkan bahwa program MPS memiliki dampak yang signifikan pada perubahan pelayanan perizinan yang lebih baik daripada sebelumnya sehingga dalam hal ini masyarakat, khususnya pengusaha UMKM merasa dipermudah dalam mengurus SIUP dan kemudian dengan kesadaran pribadi mendaftarkan izin usahanya melalui program MPS, sehingga inovasi yang dilakukan oleh KPP sejalan dengan pendapat Setijaningrum yang berpendapat bahwa inovasi dalam pelayanan publik harus berorientasi pada perbaikan kualitas layanan yang memuaskan pengguna layanan/masyarakat ${ }^{25}$

\section{INSTITUSIONALISME DAN TANTANGAN}

Program MPS sudah terbukti keberhasilannya, akan tetapi implementasi program MPS masih diiringi hambatan yang dapat mengancam eksistensi program di masa yang mendatang. Misalnya dapat dikategorisasi beberapa masalah yang ditemukan dalam program MPS, antara lain : 1) Politik. Politik memberikan dukungan bagi para eksekutor kebijakan sehingga kebijakan dapat dianggap mempresentasikan kepentingan masyarakat. Untuk saat ini Walikota Kediri sangat mendukung program MPS, akan tetapi jika terjadi pergantian kepemimpinan politik yang akan mengakibatkan berubahnya arah dukungan, maka harus segera dipikirkan eksistensi program MPS di masa mendatang. 2) Anggaran. Anggaran berfungsi sebagai logistik yang sangat penting bagi kinerja suatu organisasi. Dalam program MPS justru masalah utama yang dihadapi adalah dari segi anggaran, sebab selama ini pegawai KPP yang diterjunkan ke masyarakat secara langsung belum mendapatkan insentif yang benar-benar layak ${ }^{26}$. Mereka bekerja di luar kantor tanpa adanya tambahan uang kerja yang benar-benar sesuai dengan kinerja mereka, sehingga dikhawatirkan di masa

\footnotetext{
25 Erna Setijaningrum. 2009. Inovasi pelayanan publik. Surabaya : PT Revka petra media. Hal 83

${ }^{26}$ Wawancara dengan kepala KPP. 24/08/12
} 
mendatang terjadi penolakan yang justru terjadi di dalam organisasi KPP sendiri. 3) Partisipasi masyarakat. Adanya partisipasi masyarakat dalam suatu kebijakan akan manghasilkan suatu implementasi kebijakan yang lebih komprehensif, sebab masyarakat juga ikut serta dan bertanggungjawab atas eksistensi sebuah kebijakan. Dalam program MPS dapat dinilai ketika proses inisiasi program yang belum secara penuh melibatkan peran serta masyarakat, hal ini sangat penting sebab masyarakat harus merasa ikut memiliki program MPS yang dapat memudahkan mereka. Untuk itu KPP harus lebih giat lagi dalam melakukan sosialisasi terutama jika ingin melibatkan masyarakat dalam program inovasi berikutnya, ataupun ingin mengembangkan program MPS lebih lanjut.

Kedepannya program MPS diharapkan semakin meningkatkan mobilitasnya, mungkin dengan penambahan mobil MPS yang sampai saat ini masih satu unit dan juga diberikannya anggaran yang lebih kepada program MPS sehingga pegawai dapat menerima insentif yang sesuai dengan kinerjanya di lapangan. Ide lain dari KPP adalah ingin membuat sebuah sistem pelayanan publik yang terintegrasi dengan lembaga lainnya dalam satu tempat sehingga sangat memudahkan masyarakat, misalnya membentuk sebuah bazar pelayanan publik yang didalamnya terdapat berbagai macam jenis pelayanan publik yang dibutuhkan masyarakat, sehingga masyarakat tidak perlu mengurus pelayanan secara berbelit-belit ${ }^{27}$. Kemudian dari kepala KPP sendiri mengharapkan terjadinya integrasi seluruh sistem pelayanan publik di kota kediri dalam satu lokasi saja, mungkin dapat dalam bentuk lembaga atau program MPS sendiri ${ }^{28}$. Selain itu agar progam MPS terus berlanjut strategi yang dilakukan oleh KPP adalah dengan terus melaksankan progam MPS secara terus menerus yang biasanya terjadwal pada hari selasa dan rabu setiap minggunya, bahkan pernah dilakukan empat kali dalam seminggu serta terus mengusahakan

\footnotetext{
${ }^{27}$ Wawancara dengan staf KPP. 06/08/12

${ }^{28}$ Wawancara dengan kepala KPP. 24/08/12
}

dukungan dari Walikota Kediri agar bersedia hadir dalam pelaksanaan program MPS sehingga masyarakat tertarik untuk mengurus perizinan. Adanya kontinuitas program akan membuat masyarakat yang merasa dipermudah oleh program MPS dalam mengurus perizinan akan terus mencari dan menggunakan program MPS sehingga semakin tinggi tuntutan masyarakat terhadap program MPS akan membuat program ini dipastikan keberlanjutannya.

\section{LESSON LEARNED}

Menggagas inovasi tidaklah mudah dan bahkan sampai tahap implementasinya pun juga selalu diiringi dengan berbagai hambatan. Seperti progam MPS yang dilaksanakan oleh KPP merupakan awal dari pemikiran out of the box dari tim sembilan ${ }^{29}$. Artinya program ini memang dibuat atas dasar pemikiran yang cepat di luar rasionalitas birokrasi yang harus tunduk pada aturan. Pegawai KPP sendiri menilai bahwa masyarakat harus segera dilayani dengan cara yang lebih baik, lebih mudah serta lebih cepat, sehingga masyarakat menjadi puas dengan kinerja KPP. Kemudian dari proses perencanaan, implementasi serta evaluasi program MPS dapat ditemukan ciri khas yaitu selalu adanya diskusi dan rapat bersama tim sembilan untuk mencapai kesepakatan bersama, hal ini dapat juga disebut dengan pembelajaran tim dimana terjadi proses menyejajarkan dan mengembangkan tim untuk menciptakan hasil yang benar-benar diinginkan oleh anggotanya. ${ }^{30} \mathrm{Hal}$ tersebut sangat penting karena dalam kerangka knowledge management inilah terjadi perubahan orientasi strategi organisasi dari market based view menuju resource based view, pandangan ini diyakini sebagai kunci keberhasilan organisasi. ${ }^{31}$

Keberhasilan suatu program yang dilakukan oleh sebuah daerah sudah seharusnya dapat menginspirasi daerah lain

\footnotetext{
${ }^{29}$ Wawancara dengan staf KPP. 13/08/12

30 M.R. Khairul Muluk. 2008. Knowledge management : kunci sukses inovasi pemerintahan daerah. Malang : Bayumedia publishing. Hal 79

${ }^{31}$ Ibid. Hal 13
} 
untuk melakukan hal yang sama. Oleh karena itu untuk mendapatkan manfaat bersama dari keberhasilan program MPS dapat disajikan berikut ini beberapa poin penting yang dapat dijelaskan : 1) Inisiasi. Proses inisasi dalam program MPS menunjukkan pentingnya diskusi dan rapat yang saling memberikan masukan dan kritikan. Jadi selama proses inisiasi pasti terjadi proses sharing knowledge dalam tim sembilan sebagai inisiator utama. Hal ini sangat penting karena dengan adanya sikap saling memberi masukkan dan kritikan maka kesimpulan yang dihasilkan akan semakin komprehensif. 2) Implementasi. Implementasi program MPS dapat dikatakan out of the box dari kebiasaan berpikir dalam birokrasi pada umumnya. Dimana yang biasanya hal yang penting dilakukan adalah membuat aturan legal formal yang tentu saja memakan banyak waktu, akan tetapi program MPS diciptakan tanpa memiliki satu aturan apapun yang menjadi dasar berdirinya program MPS, yang terpenting adalah bahwa program MPS tidak melanggar aturan apapun yang telah ada sebelumnya. Hal ini menunjukkan bahwa kini sebenarnya birokrasi dapat berpikir out of the box, meskipun tidak meninggalkan aturan yang berlaku. Kemudian mekanisme jemput bola dalam program MPS menunjukkan semangat birokrasi untuk melayani masyarakat, tidak seperti dahulu yang biasanya birokrasi harus lebih tinggi kedudukannya dari masyarakat. Kini semua sudah berubah, birokrasi harus adatif terhadap tuntutan masyarakat. Program MPS ini adalah salah satu buktinya. 3) Institusionalisme. Pelembagaan programprogram inovasi biasanya memiliki kesulitan yang cukup tinggi karena dapat menimbulkan resistensi dari dalam internal birokrasi sendiri, akan tetapi selama suatu program benar-benar dibutuhkan masyarakat dan didukung oleh masyarakat maka pelembagaan dan keberlanjutan program dapat dipastikan. Termasuk program MPS yang mempermudah masyarakat dalam mengurus perizinan sehingga masyarakat akan selalu mendukungnya.
Selain itu dapat juga ditampilkan beberapa faktor kunci yang menentukan keberhasilan program MPS antara lain : 1) Faktor pendukung : - Kepemimpinan. Dalam hal ini kepemimpinan dari kepala KPP menonjol dalam memberikan dukungan penuh kepada para stafnya dalam melaksanakan tugas-tugas pelayanan perizinan. Kemampuan mendelegasikan kekuasaan pada tim sembilan juga menunjukkan adanya komitmen untuk saling bekerjasama dalam melaksanakan tugas pelayanan, selain itu kepala KPP juga berani untuk mengambil resiko dan berkorban demi kepentingan masyarakat, sebagai contoh adalah penggunaan mobil dinas yang seharusnya digunakan sebagai sarana transportasi sehari-hari dalam menjalankan tugas menjadi mobil program MPS. Sumber Daya Manusia. Merupakan faktor penting yang tidak dapat dihilangkan dalam keberhasilan program MPS. Dari semua alur baik dari proses inisiasi maupun implementasi banyak tergantung pada kemampuan sumber daya manusia, terutama sumber daya manusia dalam tim sembilan. Kemudian dari segi faktor penghambat program MPS antara lain : 2) Faktor penghambat : - Anggaran. Masalah ini merupakan masalah yang dapat menggerogoti keberhasilan program MPS. Jika sekarang program MPS dinilai berhasil, dapat terjadi kegagalan di masa mendatang karena kurangnya insentif yang diberikan kepada pegawai KPP yang turun di lapangan untuk melaksanakan program MPS sehingga pegawai akan enggan melaksankan program MPS lagi.

\section{PELUANG REPLIKASI}

Suatu inovasi yang dilakukan oleh pemerintah daerah akan semakin bermanfaat jika mampu direplikasi oleh pemerintah daerah lainnya. Dalam hal ini kantor pelayanan perizinan sudah berupaya untuk saling berbagi pengalaman dalam melaksanakan program MPS, salah satu upaya yang dilakukan oleh KPP adalah dengan mengikuti pameran pelayanan publik dan budaya kerja Jawa Timur pada tahun 2011. Selama mengkuti pameran tersebut 
banyak pemerintah daerah yang saling berbagi pengalaman melaksanakan inovasi. Khusus untuk program MPS yang mendirikan stand disana banyak mendapat apresiasi dari pemerintah daerah yang lain karena dinilai keberhasilannya, akan tetapi tim-tim dari pemerintah dari daerah lain justru lebih banyak bertanya bagaimana cara untuk mendapatkan mobil secara gratis untuk melaksanakan program MPS daripada berdiskusi mengenai implementasi program $\mathrm{MPS}^{32}$. Hal ini menunjukkan bahwa masih banyak terdapat perbedaan mindset antar pemerintah daerah yang menggunakan mindset birokrasi klasik yang mementingkan aspek legal formal dan fisik daripada birokrasi modern yang adaptif dan responsif terhadap tuntutan masyarakat. KPP sendiri terbuka bagi siapa saja baik pemerintah daerah, lembaga privat, universitas maupun organisasi non-pemerintah yang ingin berbagi pengalaman inovasi dan ingin melakukan replikasi program MPS.

Berdasarkan pengalaman KPP sendiri sebelum suatu lembaga melakukan inovasi maka setidaknya harus memenuhi dua syarat berikut ini, yaitu pertama, lembaga harus sudah memiliki sumber daya manusia yang memiliki kompetensi dan semangat perubahan yang tinggi, dan juga harus memiliki pemimpin yang sesuai dengan visi yang telah dibuat bersama, kemudian yang kedua lembaga harus memiliki atau mendapatkan dukungan politik secara luas, sehingga memudahkan lembaga untuk melaksankan inovasi yang telah ditetapkan. Kedua prasyarat tersebut harus dipenuhi agar inovasi dapat terimplementasikan dengan baik. Bagi daerah-daerah lain yang hendak melakukan replikasi program MPS, KPP sudah mempunyai kerangka acuan utama yang dimiliki oleh KPP untuk melakukan replikasi adalah tersedianya sumber daya manusia yang dapat bekerja sama dalam sharing knowledge, dalam hal ini adalah sumber daya manusia yang tergabung dalam tim sembilan. Adanya tim sembilan akan membantu replikasi yang akan dilakukan karena dalam setiap proses iniasi, implementasi hingga evaluasi disitulah tim sembilan pasti terlibat, sehingga mereka pasti sangat mengetahui bagaimana cara untuk melakukan, apa saja cara yang harus dilakukan serta menjelaskannya untuk melakukan transfer pengetahuan yang sangat berguna bagi proses replikasi.

\footnotetext{
${ }^{32}$ Wawancara dengan staf KPP. 13/08/12
} 


\section{DAFTAR PUSTAKA}

\section{Buku :}

Agus Dwiyanto (Ed). 2008. Mewujudkan good governance melalui pelayanan publik. Jogjakarta : Gadjah mada university press.

Setijaningrum, Erna. 2009. Inovasi pelayanan publik. Surabaya : PT Revka petra media.

Jusuf Irianto, dkk. 2009. Manajemen sumber daya manusia berbasis kompetensi untuk pelayanan publik. Surabaya : Airlangga university press.

Muluk, M.R. Khairul. 2008. Knowledge management : kunci sukses inovasi pemerintahan daerah. Malang : Bayumedia publishing.

Pasolong, Harbani. 2010. Teori administrasi publik. Bandung : Alfabeta.

Rahardjo Adisasmita. 2011. Manajemen pemerintah daerah. Jogjakarta : Graha ilmu. Ratminto dan Winarsih, Atik Septi. 2006. Manajemen pelayanan : pengembangan model kenseptual, penerapan citizen charter dan standar pelayanan minimal. Jogjakarta : Pustaka pelajar.

Suaedi, Falih dan Wardiyanto, Bintoro (Ed). 2010. Revitalisasi administrasi negara : reformasi birokrasi dan e-government. Jogjakarta : Graha ilmu.

Thoha, Miftah. 2010. Birokrasi dan politik di Indonesia. Jakarta : PT Rajagrafindo persada.

\section{Hasil penelitian :}

Inovasi pelayanan pro-miskin : sembilan studi kasus di Indonesia. 2006. Bank dunia.

Praktek-praktek yang baik dalam pemberdayaan UKM. 2009. LGSP, Usaid \& Dirjen PU Depdagri. Seri manajemen pelayanan publik. Survei tata kelola ekonomi daerah 2011.

Survei kabupaten/kota di Indonesia untuk bidang penanaman modal. 2009. Komite pemantau pelaksanaan otonomi daerah (KPPOD) dan badan koordinasi penanaman modal (BKPM).

Survei tata kelola ekonomi daerah 2011. Komite pemantau pelaksanaan otonomi daerah (KPPOD)

\section{Sumber lain :}

Laporan data akumulasi SIUP MPS 2011 \& 2012 (tidak dipublikasikan)

Kediri dalam angka tahun 2011. BPS Kota Kediri

\section{NARASUMBER}

Kepala kantor pelayanan perizinan (KPP) kota kediri : Agus suhariyanto, S.sos, M.Si

Staf kantor pelayanan perizinan (KPP) kota kediri : Adi wicaksono, Bayu aryo serta Rama aji sasongko. 